\title{
Primary mucinous adenocarcinoma of the bladder with signet-ring cells:
}

\section{case report}

\author{
Hospital Professor Edmundo Vasconcelos, São Paulo, Brazil
}

Marcelo Lorenzi Marques

- Gabriel Salum D'Alessandro

- Daher Cezar Chade

- Valéria Pereira Lanzoni

- Samuel Saiovici

- Cláudio José Ramos de Almeida

\section{INTRロDUCTIDN}

Bladder adenocarcinomas account for 0.5 to $2 \%$ of all malignant tumors of the bladder. The mucinous and signet-ring cell subtypes are rare and correspond to $20 \%$ of these tumors. ${ }^{1,2}$

Intramural tumor growth causes late symptoms. This delays the diagnosis and results in a poorer prognosis than for urothelial tumors. ${ }^{1-3}$

There are a variety of histological types among adenocarcinomas, including papillary, glandular, adenoid cystic, clear cell, mucinous and signet-ring cell carcinomas. The last of these types is characterized by the presence of intracellular vacuoles filled with mucin that displace the hyperchromatic nuclei. ${ }^{2}$

Because of the rarity of primary mucinous adenocarcinoma and the difficulties and particularities in diagnosing the primary tumor site, we present here a case of primary mucinous adenocarcinoma of the bladder with signet-ring cells.

\section{CASE REPLRT}

A 57-year-old male patient presented with a six-month history of painless intermittent macroscopic hematuria without coagula. The patient was a smoker and an alcoholic (Child B

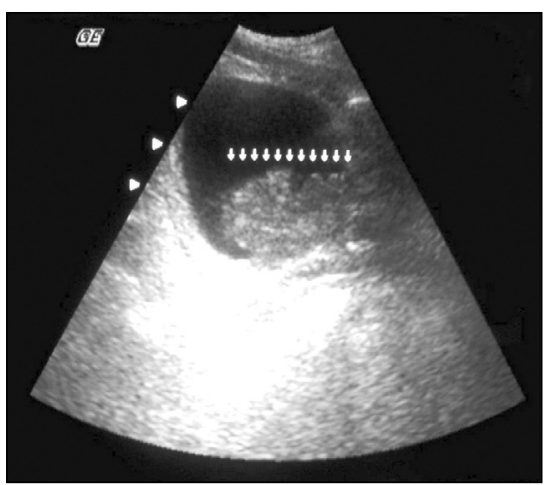

Figure 1. Abdominal ultrasound showing intravesical mass $(10 \mathrm{~cm}$ in diameter). alcoholic liver cirrhosis). He presented weight loss, ascites and lower limb edema. There was no palpable abdominal tumor and digital rectal examination was normal.

Ultrasound and abdominal tomography revealed ascites, cirrhotic liver with nodules (largest nodule measuring $7.5 \mathrm{~cm}$ in diameter) and an intravesical mass of $10 \mathrm{~cm}$ in diameter that was continuous to the prostate and involved the floor and left lateral wall (Figures 1 and 2).

Cystoscopy made it possible to see a sessile mass in the left hemitrigone, involving the meatus, left lateral wall, posterior wall and part of the anterior wall, showing rough papillomatous areas and other areas with intact mucosa. Total resection of the intravesical tu-
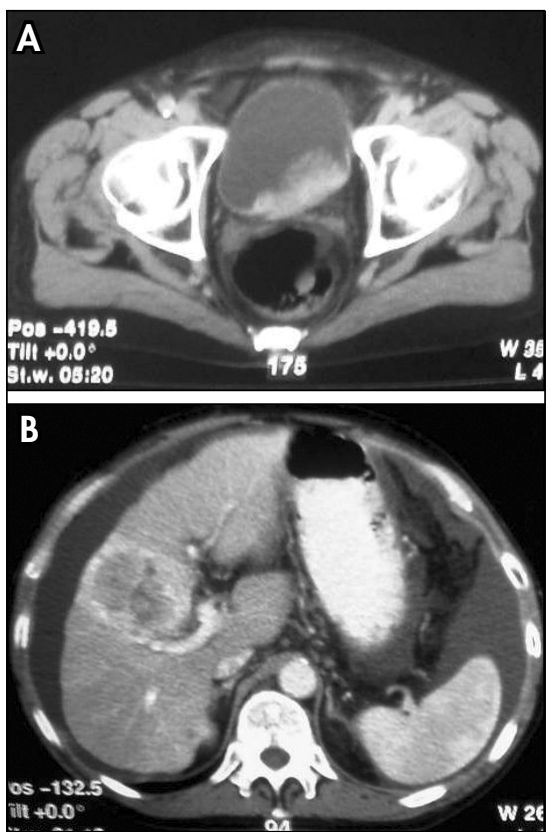

Figure 2. A) Computer tomography showing intravesical mass. B) Nodule measuring $7.5 \mathrm{~cm}$ in diameter in a cirrhotic liver suggesting metastasis.

\section{ABSTRACT}

CONTEXT: Primary adenocarcinomas of the bladder are uncommon and usually occur by contiguity with or hematogenic dissemination of other adenocarcinomas such as colorectal, prostate and gynecological tract carcinomas. Mucinous and signet-ring cell histological patterns are even rarer and it is often difficult to morphologically distinguish them from metastatic colorectal adenocarcinoma.

CASE REPORT: We present and discuss a rare case of primary mucinous adenocarcinoma of the bladder with signet-ring cells in a 57-year-old male patient. Other primary sites for the tumor had been excluded and, in the absence of digestive tract tumor and for confirmation that it was a primary bladder tumor, an immunohistochemistry study was performed.

KEY WORDS: Urinary bladder. Urinary bladder neoplasms. Mucinous adenocarcinoma. Immunohistochemistry. Signet ring cell carcinoma. 
mor could not be performed because of its size and infiltration. On the other hand, the main objective of this procedure was diagnosis.

The histological findings were that this was a case of mucinous adenocarcinoma with signet-ring cells infiltrating the lamina propria and musculature, with preservation of the mucosa.

Because of the rarity of primary bladder tumors with these histological features, rigid rectosigmoidoscopy, colonoscopy, upper digestive endoscopy, pelvis resonance and laparoscopy together with liver biopsy were sequentially performed with the aim of detecting possible primary gastrointestinal cancer. Histopathological analysis of the liver fragment revealed mucinous adenocarcinoma associated with cirrhosis.
In view of the absence of a digestive tract tumor and to confirm the primary bladder origin of the tumor, immunohistochemical analysis was performed. The tumor was found to be diffusely immunopositive for Muc- 2 and p63 and focally immunopositive for CK7 and CK20, but negative for TTF-1, PSA, Muc-5AC and CDX-2. The immunohistochemical panel, together with the histological characteristics, characterized a mucus-secreting urothelial carcinoma (Figure 3).

DISCUSSION

Primary bladder adenocarcinomas are uncommon and usually occur by contiguity with or hematogenic dissemination of other adenocarcinomas such as colorectal, prostate and gynecological tract carcinomas. ${ }^{3}$ The
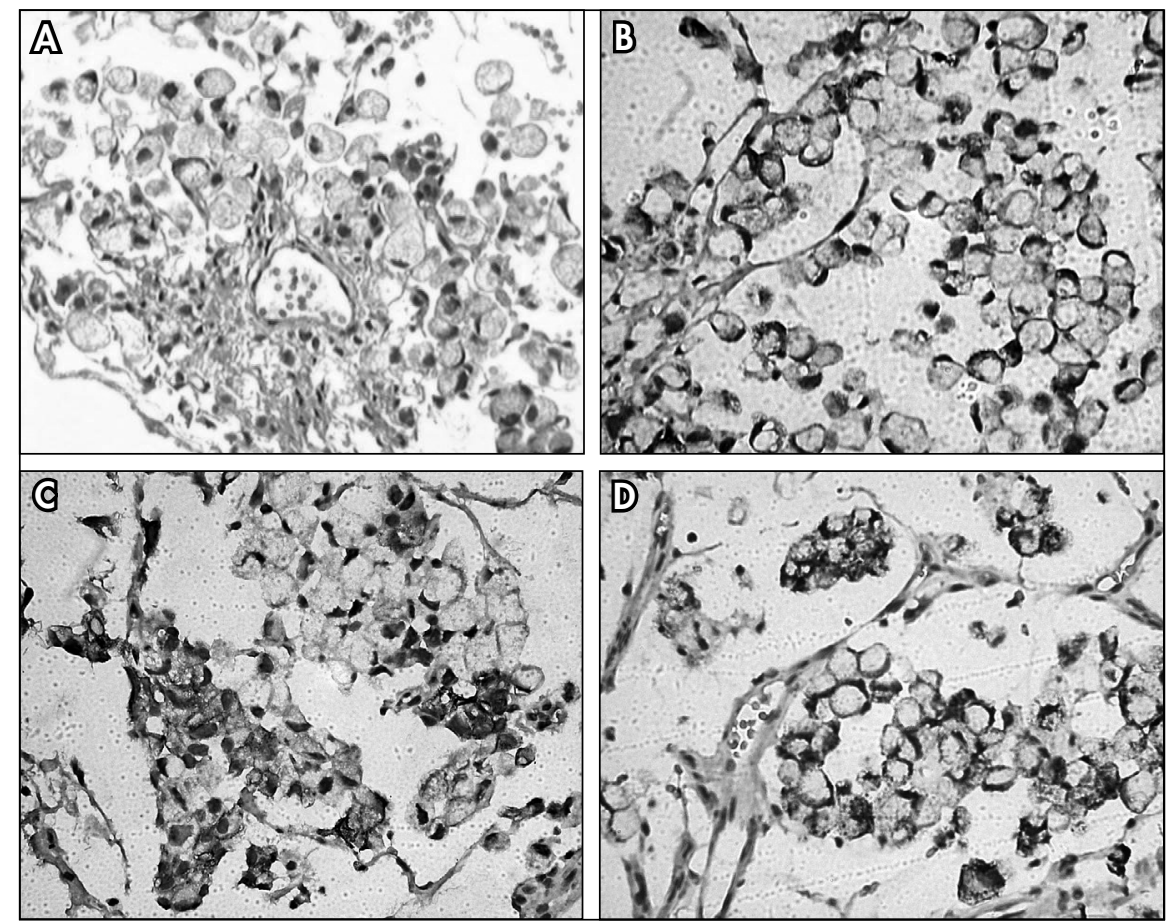

Figure 3. A) Mucinous adenocarcinoma of the bladder with signet-ring cells (hematoxylin-eosin, 200 x). B) Immunohistochemistry positive for Muc-2. C) Immunohistochemistry positive for CK7. D) Immunohistochemistry positive for CK20. (100 x). mucinous and signet-ring cell histological patterns are even rarer and it is often difficult to morphologically distinguish them from metastatic colorectal adenocarcinoma.

Immunohistochemical analysis using a panel of specific markers is an important alternative for etiological differentiation of these tumors. A CDX-2 and CK20-positive and CK7-negative profile is indicative of digestive tract adenocarcinoma, particularly colorectal carcinoma, and is rare in urothelial tumors, which normally express $\mathrm{CK} 7$ alone or together with CK20 $0^{3}$ and do not express CDX-2.

Few studies on the expression of the cytokeratins CK20 and CK7 in primary bladder adenocarcinoma cases are available in the literature. Torenbeek et al. ${ }^{4}$ observed the expression, at least focally, of CK7 in $82 \%$ of cases and CK20 in $73 \%$, whereas a CK20-positive and CK7-negative profile was detected in only $29 \%$ of the cases of primary adenocarcinomas of the bladder. ${ }^{3}$

The expression of markers for mucinproducing tumors such as Muc-2 and Muc$5 \mathrm{AC}$ is very heterogeneous and is observed in a wide variety of tumors, particularly those originating from the intestinal tract. ${ }^{5}$ Immunohistochemical evaluation of these specific markers to help in diagnosing carcinomas for which the primary origin is uncertain is not usually recommended.

\section{CONCLUSIONS}

Primary adenocarcinoma of the bladder is very rare and its precise diagnosis through conventional methods is difficult to achieve. For this reason, immunohistochemical analysis has major importance in determining the final diagnosis. In this case, the panel was immunopositive for Muc-2, CK7 and CK20 and immunonegative for CDX-2; this, together with the histological findings, characterized a mucus-secreting urothelial carcinoma. However, the markers for mucin-producing tumors, such as Muc-2 and Muc-5AC, are also observed in a wide variety of other tumors. Therefore, investigation of these markers is not usually recommended.

\section{REFERENCES}

1. Zaghloul MS, Nouh A, Nazmy M, et al. Long-term results of primary adenocarcinoma of the urinary bladder: a report on 192 patients. Urol Oncol. 2006;24(1):13-20.

2. Fiter L, Gimeno F, Martin L, Gómez Tejeda L. Signet-ring cell adenocarcinoma of bladder. Urology. 1993;41(1):30-3.

3. Wang HL, Lu DW, Yerian LM, et al. Immunohistochemical distinction between primary adenocarcinoma of the bladder and secondary colorectal adenocarcinoma. Am J Surg Pathol. 2001;25(11):1380-7.
4. Torenbeek R, Lagendijk JH, Van Diest PJ, Bril H, van de Molengraft FJ, Meijer CJ. Value of a panel of antibodies to identify the primary origin of adenocarcinomas presenting as bladder carcinoma. Histopathology. 1998;32(1):20-7.

5. Lau SK, Weiss LM, Chu PG. Differential expression of MUC1, MUC2, and MUC5AC in carcinomas of various sites: an immunohistochemical study. Am J Clin Pathol. 2004;122(1):61-9.
Sources of funding: None Conflicts of interest: None

Date of first submission: July 3, 2006

Last received: September 10, 2007

Accepted: Septmeber 12, 2007 
AUTHDR INFDRMATIDN

Marcelo Lorenzi Marques, MD. Resident, Urology Service, Hospital Professor Edmundo Vasconcelos, São Paulo, Brazil.

Gabriel Salum D'Alessandro, MD. Resident, General Surgery, Hospital Professor Edmundo Vasconcelos, São Paulo, Brazil.

Daher Cezar Chade, MD. Resident, Urology Service, Hospital Professor Edmundo Vasconcelos, São Paulo, Brazil.

Valéria Pereira Lanzoni, MD. Attending physician, Pathology Service, Hospital Professor Edmundo Vasconcelos, São Paulo, Brazil.

Samuel Saiovici, MD. Aftending physician, Urology Service, Hospital Professor Edmundo Vasconcelos, São Paulo, Brazil.

Cláudio José Ramos de Almeida, MD. Head of the Urology Service, Hospital Professor Edmundo Vasconcelos, São Paulo, Brazil.

\section{Address for correspondence:}

Samuel Saiovici

Rua Borges Lagoa, 1450 - Vila Clementino

São Paulo (SP) - Brasil - CEP 04038-905

Tel. (+55 11) 5080-4000

E-mail: saiovici@terra.com.br

Copyright $\odot$ 2007, Associação Paulista de Medicina
RESUMD

Adenocarcinoma mucinoso primário da bexiga com células em anel de sinete: relato de caso

CONTEXTO: Adenocarcinomas vesicais primários são incomuns, o habitual é o comprometimento por contigüidade ou via hematogênica de outros adenocarcinomas como colorretal, próstata e trato ginecológico. O padrão histológico correspondente ao mucinoso e com células em anel de sinete é mais raro e, muitas vezes, há dificuldade em distingui-lo morfologicamente do adenocarcinoma colorretal metastático.

RELATO DE CASO: Apresentamos e discutimos um caso de adenocarcinama mucinoso com células em anel de sinete primário da bexiga em um paciente masculino, de 57 anos. Foram excluídos outros sítios primários do tumor e, na ausência de tumor do trato digestivo e para confirmação de tumor vesical primário realizou-se estudo imunoistoquímico.

PALAVRAS-CHAVE: Bexiga urinária. Neoplasias da bexiga urinária. Adenocarcinoma mucinoso. Imunohistoquímica. Carcinoma de células em anel de sinete. 